\title{
The use of organic concentrate in feeding quail
}

\author{
Devot Ndaiikengurukiye, Firaya Akhmetzianova, Aliya Kashaeva*, and Delius Sharipov \\ Department of Feeding, Kazan State Academy of Veterinary Medicine named after N.E. Bauman, Kazan, 420029, Russia
}

\begin{abstract}
The article presents the results of the effect of partial replacement of mixed feeds with organic concentrate based on dry bird droppings (DBD) on the preservation of quail, quantitative and qualitative rates of egg productivity. For the laboratory experiment, 5 experimental groups of Manchurian quail were formed by the analogous pair comparison method. The quail of the control group consumed all-in-one feed (AF), for the quail of the experimental groups (I, II, III, and IV) part of the AF - 10, 15, 20 and $25 \%$ by weight - was replaced with organic concentrate. Results of studies reveal that the introduction of $10 \%$ of organic concentrate into the AF contributed to improved feed intake and livestock safety, increased egg productivity and reduced feed consumption per unit of output. With respect to the indicators of biological usefulness, toxicological and sanitary-epidemiological safety, quail eggs treated with the organic concentrate met the requirements of GOST and TR TS 021/2011 "On food safety".
\end{abstract}

\section{Introduction}

Currently, industrial poultry farming is the most intensively developing agricultural sector in many countries of the world, providing the population with highly nutritious and affordable food [1, 2]. When preparing all-in-one mixed feeds for poultry, foddergrain crops (corn, wheat, barley, oats, millet) are being increasingly used. Their proportion in mixed feed reaches $65-80 \%$ by weight $[3,4]$. At the same time, the observed population growth causes an increased demand for fodder-grain crops, thus resulting in their cost increase and the decrease of profitability of poultry farming.

In this regard, many researchers are looking for alternative cheaper sources of energy and protein for poultry $[5,6]$. One promising alternative feed is processed dry bird droppings (DBD). The chemical composition of the DBD is close to sunflower press cake and meal. The content of crude protein is $23-28 \%$, fiber $12-14 \%$, nitrogen-free extractive substances $-30-37 \%$, crude fat $-3-5 \%$, ash $-11-13 \%$, calcium - 3-9\%, and up to $5 \%$ of phosphorus. Crude protein is represented by a complex of essential amino acids, ( \%): glycine 1.1-1.3; aspartic acid 1.01-1.02; glutamic acid 1.2-1.3; lysine $0.7-0.8$; phenylalanine $0.7-0.8$; leucine $0.67-0.85$; valine 0.6 ; serine $0.5-0.7$; threonine $0.5-0.6$; isoleucine $0.4-0.5$; phenylalanine $0.36-0.45$; arginine $0.35-0.42$; proline $0.2-0.3$; tyrosine $0.17-0.20$; histidine $0.15-0.20$. $100 \mathrm{~g}$ of DBD contains (mg): iron 367-900; zinc 12-39; manganese 15-38; copper - 0.5; cobalt $1.0-1.2[7,8]$.

Taking into account that one broiler emits one kilogram of droppings during one production period, broiler and egg poultry farming is one of the main sources of environmental pollution. In the air near poultry farms, an increase in carbon dioxide $(\mathrm{CO} 2)$, ammonia (NH3), hydrogen sulfide (H2S), carbon monoxide (CO), methane ( $\mathrm{CH} 4)$ is recorded. Cyanides, nitrates, heavy metals accumulate in droppings and pathogenic microorganisms like salmonella, streptococci and others can be present there $[9,10]$.

Currently, many methods have been developed for decontaminating bird droppings: combined, chemical, biotechnological, physical and composting methods [11, 12]. According to the results of a number of research works, it was found that the use of processed and decontaminated bird droppings in ruminant feeding has a positive effect on livestock farming and economic indicators $[13,14]$. The widespread introduction of DBD as a feed additive will not only rationalize animal feeding, but also protect the environment from pollution. However, the literature available to us so far has very little information about the use of DBD in poultry feeding.

The purpose of the study was to study the effect of the introduction of organic concentrate based on DBD in mixed feed on feed intake, the preservation of quail, quantitative and qualitative indicators of egg productivity.

\section{Materials and methods}

Scientific and laboratory experiment with the use of organic concentrate based on DBD in feeding quail was performed in the conditions of vivarium of FSBEI HE KSAVM in 2019. To conduct the experiment, 74 quails were selected at 30 days of age and 5 experimental groups, one control and 4 experimental, were formed by the analogous pair comparison method. To conduct the experiment, 74 quails were selected at 30 days of age

* Corresponding author: aliam_81@mail.ru 
and 5 experimental groups, one control and 4 experimental ones, were formed by analogous pair comparison method. The experiment included two periods: the preparatory period ( 8 days) and the accounting period (89 days).

During the accounting period, quail of the control group was fed with factory-produced mixed feed DK-52 $-100 \%$ (main ration), and $10 \%, 15 \%, 20 \%$ and $25 \%$ of organic concentrate based on DBD was introduced into the diets of quail of experimental groups (I, II, III and IV) accordingly, in exchange for a similar amount of the main diet. Microclimate parameters, keeping conditions, planting density, feeder and watering space were the same for all experimental groups of quail. The scheme of the experiment is presented in table 1 .

Table 1. Scheme of scientific and laboratory experiment

\begin{tabular}{|l|c|c|l|}
\hline \multicolumn{1}{|c|}{ Group } & $\begin{array}{c}\text { Number of } \\
\text { quail } \\
\text { (heads of } \\
\text { poultry) }\end{array}$ & $\begin{array}{l}\text { Duration of } \\
\text { experiment } \\
\text { (days) }\end{array}$ & $\begin{array}{l}\text { Conditions of the } \\
\text { accounting period }\end{array}$ \\
\hline Control & 15 & 97 & $\begin{array}{l}\text { Main diet (MD) } \\
\text { AF }\end{array}$ \\
\hline I-experimental & 15 & 97 & $\begin{array}{l}\text { MD+10\% } \\
\text { organic } \\
\text { concentrate }\end{array}$ \\
\hline II-experimental & 14 & 97 & $\begin{array}{l}\text { MD+15 \% } \\
\text { organic } \\
\text { concentrate }\end{array}$ \\
\hline $\begin{array}{l}\text { III- } \\
\text { experimental }\end{array}$ & 15 & 97 & $\begin{array}{l}\text { MD+20\% } \\
\text { organic } \\
\text { concentrate }\end{array}$ \\
\hline $\begin{array}{l}\text { IV- } \\
\text { experimental }\end{array}$ & 15 & 97 & $\begin{array}{l}\text { MD+25 \% } \\
\text { organic } \\
\text { concentrate }\end{array}$ \\
\hline
\end{tabular}

In the course of the experiment, the preservation of livestock, eatability of the feeds measured by daily weighing of the specified feeds and their residues, egg productivity by the number and weight of laid eggs were recorded. In addition, biochemical, toxicological and microbiological studies of eggs were carried out. Biological full-value of eggs was evaluated by their chemical composition, their toxicological safety - by the determination of heavy metals (lead and cadmium), microbiological safety - by the determination of coliform bacteria (CB) and colony forming mesophilic aerobic and facultative anaerobic microorganisms (KMAFAM), as well as pathogenic microorganisms, including salmonella.

Eggs were studied in the educational and research laboratory of the FSBEI HE KSAVM and the Test Center of the Federal State Budgetary Institution "Tatar Interregional Veterinary Laboratory". Chemical analysis of eggs was carried out according to standard methods $[15,16]$, the content of heavy metals (lead, cadmium) was determined by atomic absorption spectrometry according to MUK 4.1.986-00, BGKP according to GOST 31747-2012, KMAFAM according to GOST 10444.15-94; and that of pathogenic microorganisms, including salmonella according to GOST 31659-2012.

All data obtained during the research were subjected to statistical processing using the Microsoft Excel program. The reliability of intergroup differences was determined using Student's criterion.

\section{Results and discussion}

One of the main factors that make it possible to judge the quality of feed is its consumption (Table 2).

Table 2. Dynamics of feed intake (g)

\begin{tabular}{|c|c|c|c|c|c|}
\hline \multirow[b]{2}{*}{$\begin{array}{l}\text { Age of } \\
\text { quail, days }\end{array}$} & \multicolumn{5}{|c|}{ Group } \\
\hline & $\begin{array}{l}\overline{0} \\
\dot{\Xi} \\
\end{array}$ & 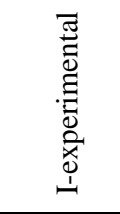 & 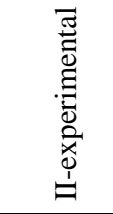 & 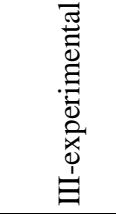 & 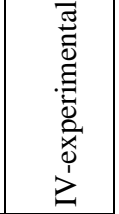 \\
\hline $38-55$ & 27.47 & 27.47 & 27.47 & 27.47 & 27.47 \\
\hline $56-70$ & 30.00 & 30.00 & 30.00 & 30.00 & 30.00 \\
\hline $71-85$ & 30.00 & 30.00 & 30.00 & 30.00 & 30.00 \\
\hline $86-100$ & 32.40 & 32.40 & 31.90 & 31.90 & 31.85 \\
\hline \begin{tabular}{|l|}
$101-115$ \\
\end{tabular} & 32.21 & 32.60 & 31.95 & 31.65 & 31.60 \\
\hline \begin{tabular}{|l|}
$116-126$ \\
\end{tabular} & 32.17 & 32.65 & 32.02 & 31.55 & 31.38 \\
\hline $\begin{array}{l}\text { Total for } \\
89 \text { days of } \\
\text { accounting } \\
\text { period } \\
\end{array}$ & 2717.48 & 2728.61 & 2704.41 & 2694.49 & 2691.39 \\
\hline $\begin{array}{l}\text { Average } \\
\text { per day }\end{array}$ & 30.53 & 30.69 & 30.39 & 30.28 & 30.24 \\
\hline $\begin{array}{l}\text { In \% of } \\
\text { the control } \\
\text { group }\end{array}$ & 100.00 & 100.52 & 99.54 & 99.18 & 99.05 \\
\hline
\end{tabular}

Based on the data of the table, it is noted that the addition of up to $25 \%$ of organic concentrate based on DBD to mixed feeds did not have a negative effect on feed intake, there was no significant difference between the groups in terms of feed intake. The maximum feed consumption was observed in quail of the first experimental group (30.7 $\mathrm{g}$ on average per head, which is $0.52 \%$ more, and the indicator in the second, third, and fourth groups was $0.46,0.82,0.95 \%$ less, respectively, compared to control.

The preservation of livestock in the control group when consuming standard mixed feed, as well as in the III and IV experimental groups, when $20 \%$ and $25 \%$ of organic concentrate was introduced into the composition of the feed, amounted to $93.33 \%$. In the I and II groups with a content of $10 \%$ and $15 \%$ of the concentrate in the composition of the feed, the preservation was $100 \%$. This suggests that the introduction of a moderate amount of organic concentrate based on DBD did not adversely affect the physiological state of quail.

Egg productivity of quail of the experimental groups is presented in table 3 .

According to the results of the study, it was found that in quails of all experimental groups, the laying of eggs started 3 days earlier than in the control group. Gross egg production was highest for quail of the 1st experimental group (791 pcs.), Which is by 137 pcs. or $20.95 \%$ more than in the control group, and by 197 pcs. $(30.12 \%) ; 240$ pcs. $(36.70 \%)$; and by 265 pcs $(40.52 \%)$ more compared with analogues of the II, III and IV experimental groups. 
Intensity of laying for the accounting period of experimental feeding (Fig. 1) in quail of group I was on average $76.65 \%$, which is by $10.88 \%$ higher than in the control group and by $27.62 ; 26.62$ and $30.46 \%$, respectively, in comparison with peers of the II, III and IV experimental groups.

Figure 1 shows that the quail of group I reached $80 \%$ egg-laying at 56-70 days of age, and the peak of egglaying $(95.5 \%)$ was achieved by them at the age of 116-126 days. In quails of the control group, the intensity of laying for the accounting period did not exceed $83 \%$, and in the II, III, and IV experimental groups it was below $80 \%$. Thus, the introduction of an organic concentrate in the amount of $10 \%$ into the main diet led to an improvement in the quail egg-laying intensity.

Table 3. Egg productivity of quail of the experimental groups

\begin{tabular}{|l|c|c|c|c|c|}
\hline Indicator & \multirow{2}{*}{$\begin{array}{c}\text { Control } \\
\text { group }\end{array}$} & \multicolumn{4}{|c|}{ Experimental groups } \\
\cline { 3 - 6 } & & II & III & IV \\
\hline $\begin{array}{l}\text { Number of laying } \\
\text { hens at the } \\
\text { beginning of the } \\
\text { experiment, } \\
\text { heads. }\end{array}$ & 12 & 12 & 12 & 12 & 12 \\
\hline $\begin{array}{l}\text { Number of laying } \\
\text { hens at the end of } \\
\text { the experiment, } \\
\text { heads. }\end{array}$ & 11 & 12 & 12 & 11 & 11 \\
\hline $\begin{array}{l}\text { Age of the laying } \\
\text { of the first egg, } \\
\text { days. }\end{array}$ & 44 & 41 & 41 & 41 & 41 \\
\hline $\begin{array}{l}\text { Gross production } \\
\text { of eggs, pcs }\end{array}$ & 654 & 791 & 594 & 551 & 526 \\
\hline $\begin{array}{l}\text { Egg production } \\
\text { per hen housed, } \\
\text { pcs. }\end{array}$ & 54.50 & 65.92 & 49.5 & 45.92 & 43.83 \\
\hline $\begin{array}{l}\text { Hen-day egg } \\
\text { production, pcs }\end{array}$ & 59.45 & 65.62 & 49.50 & 50.09 & 47.81 \\
\hline $\begin{array}{l}\text { Intensity of } \\
\text { laying, \% }\end{array}$ & 69.13 & 76.65 & 57.56 & 58.25 & 55.60 \\
\hline $\begin{array}{l}\text { Average weight } \\
\text { of one egg, g }\end{array}$ & 11.98 & 11.69 & 11.27 & 11.39 & 11.42 \\
\hline $\begin{array}{l}\text { Difference with } \\
\text { respect to control, } \\
\text { g } \pm \text { ( })\end{array}$ & - & $-0,29$ & $-0,71$ & $-0,59$ & $-0,56$ \\
\hline $\begin{array}{l}\text { Difference with } \\
\text { respect to control, } \\
\%( \pm)\end{array}$ & 100.0 & 97.6 & 94.1 & 95.1 & 95.3 \\
\hline $\begin{array}{l}\text { Egg mass output, } \\
\text { kg }\end{array}$ & 7.83 & 9.25 & 6.70 & 6.28 & 6.06 \\
\hline $\begin{array}{l}\text { Difference with } \\
\text { respect to control, } \\
\text { g ( } \pm \text { ). }\end{array}$ & - & +1.41 & -1.13 & -1.55 & -1.77 \\
\hline $\begin{array}{l}\text { Difference with } \\
\text { respect to control, } \\
\%\end{array}$ & 100.0 & 118.1 & 85.6 & 80.2 & 77.4 \\
\hline $\begin{array}{l}\text { Feed consumption } \\
\text { for the entire } \\
\text { period of laying, } \\
\text { kg }\end{array}$ & 29.24 & 31.67 & 31.38 & 29.70 & 29.78 \\
\hline $\begin{array}{l}\text { Feed expenditure } \\
\text { per } 1 \text { kg of egg } \\
\text { mass, kg }\end{array}$ & 3.73 & 3.42 & 4.68 & 4.72 & 4.91 \\
\hline $\begin{array}{l}\text { Feed expenditure } \\
\text { per 100 eggs, kg }\end{array}$ & 4.47 & 4.00 & 5.28 & 5.39 & 5.66 \\
\hline
\end{tabular}

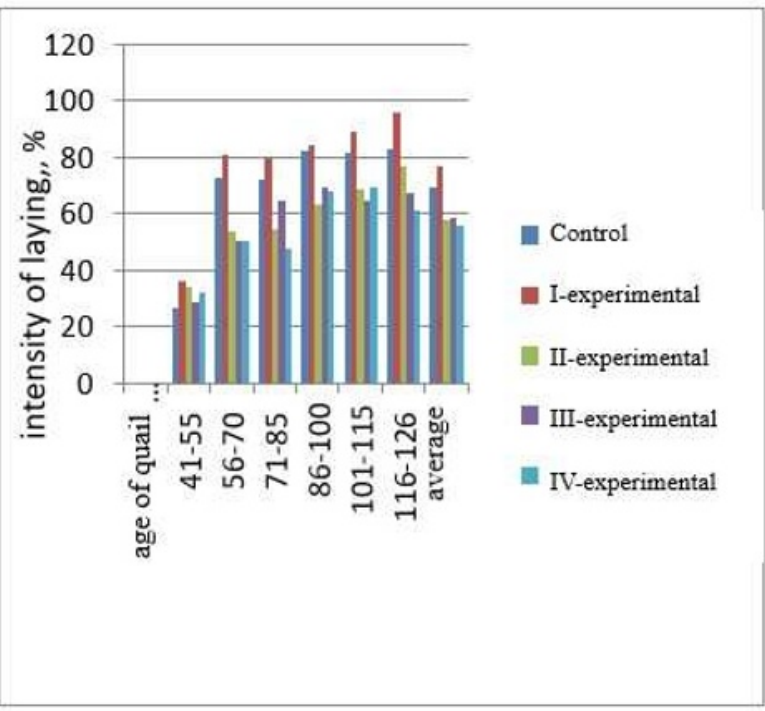

Fig. 1. Intensity of laying depending on the age of quail

One of the main parameters that affect the yield of egg mass is the weight of eggs. The dynamics of the weight of eggs depending on the age of the quail of the experimental groups is presented in Figure 2.

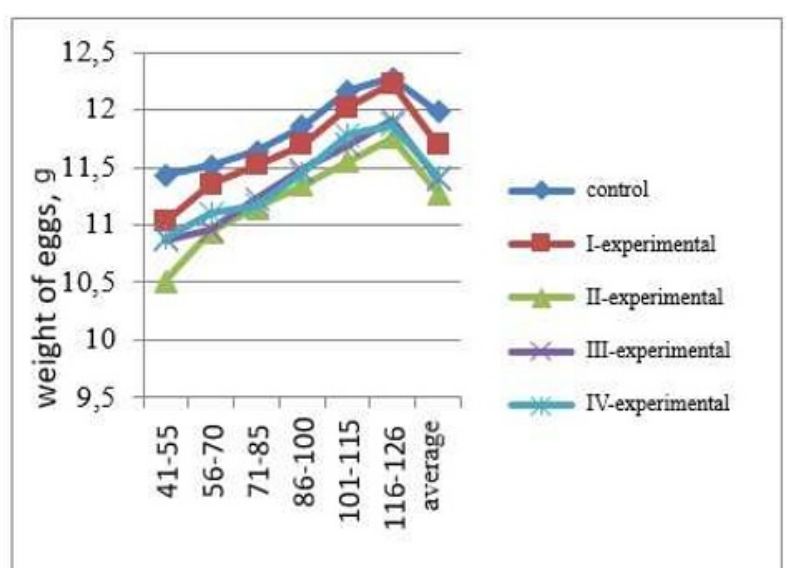

Fig. 2. The dynamics of the average weight of an egg depending on the age of quail

Studies have shown that the introduction of organic concentrate into the feed did not negatively affect the dynamics of the weight of eggs. Thus, the weight of eggs egg was increasing with age throughout the entire accounting period in all experimental groups. The maximum average weight of an egg (11.98 g) was obtained from laying hens of the control group, which is by $0.29,0.71 ; 0.59$ and $0.56 \mathrm{~g}$, respectively higher than the results of quail of the $1 \mathrm{st}, 2 \mathrm{nd}, 3 \mathrm{rd}$, and 4th experimental groups.

However, in terms of egg mass output, quail the first experimental group exceeded their analogues from the control, second, third, and fourth experimental groups, respectively, by $18.08 \% ; 32.54 \% ; 37.9 \% 1$ and $40.72 \%$. In addition, the minimum feed consumption per $1 \mathrm{~kg}$ of egg mass was observed in quails of the 1st group - $3.42 \mathrm{~kg}$, which is by $8.31 \%$ lower in comparison with the control, and accordingly by $33.78 \% ; 34.73 \%$ and $40.06 \%$ compared with their counterparts in the experimental groups (II, III and IV.). 
When feeding egg-farming birds, the nutrient and biologically active substances of the feed are spent on the formation of muscle tissue and eggs, so full value of the feed is one of the main factors affecting the quality of the eggs. In this regard, it was interesting to study the effect of organic concentrate on the chemical composition of eggs (Table 4).

Table 4. Chemical composition of eggs, $\%(n=3)$

\begin{tabular}{|c|c|c|c|c|c|}
\hline \multirow{2}{*}{ Indicator } & \multicolumn{5}{|c|}{ Group } \\
\hline & Control & I-experimental & II-experimental & III-experimental & IV-experimental \\
\hline \multicolumn{6}{|c|}{ Egg white } \\
\hline Moisture & $86.35 \pm 0.24$ & $86.41 \pm 0.23$ & $86.83 \pm 0.32$ & $86.73 \pm 0.31$ & $86.79 \pm 0.21$ \\
\hline Dry matter & $13.65 \pm 0.23$ & $13.59 \pm 0.23$ & $13.17 \pm 0.32$ & $12.93 \pm 0.56 *$ & $13.88 \pm 0.69$ \\
\hline Crude protein & $11.41 \pm 0.18$ & $11.58 \pm 0.22$ & $10.90 \pm 0.39 *$ & $10.49 \pm 0.24 * *$ & $11.32 \pm 0.74$ \\
\hline Mineral substance & $0.85 \pm 0.02$ & $0.79 \pm 0.04$ & $0.88 \pm 0.05$ & $0.90 \pm 0.02$ & $1.03 \pm 0.12 * *$ \\
\hline \multicolumn{6}{|c|}{ Yolk } \\
\hline Moisture & $51.45 \pm 0.38$ & $52.26 \pm 0.69$ & $52.24 \pm 0.39$ & $51.70 \pm 0.74$ & $51.91 \pm 0.74$ \\
\hline Dry matter & $48.55 \pm 0.38$ & $47.74 \pm 0.69$ & $47.76 \pm 0.39$ & $48.30 \pm 0.74$ & $48.09 \pm 0.74$ \\
\hline Crude protein & $16.07 \pm 0.22$ & $15.14 \pm 0.45$ & $15.79 \pm 0.09$ & $15.65 \pm 0.20$ & $15.50 \pm 0.40$ \\
\hline Crude fat & $29.32 \pm 0.62$ & $29.06 \pm 0.64$ & $29.07 \pm 0.13$ & $29.41 \pm 0.73$ & $28.48 \pm 0.47$ \\
\hline Mineral substance & $2.23 \pm 0.06$ & $2.28 \pm 0.09$ & $2.28 \pm 0.08$ & $2.18 \pm 0.06$ & $2.10 \pm 0.18$ \\
\hline
\end{tabular}

Note: $* \mathrm{P} \leq 0.05 ; * * \mathrm{P} \leq 0.005$

It was found that the introduction of organic concentrate in the composition of the feed did not adversely affect the chemical composition of the yolk mass of eggs. The difference in indicators was insignificant and statistically unreliable.

As for the chemical composition of the egg white mass, there is a closer relationship with the composition of the diet. So, with a proportion of $10 \%$ in the composition of the feed, there is no significant effect on the chemical composition of the egg white.

However, with the introduction of 15 and $20 \%$ of the concentrate in the feed composition, the crude protein in the egg white mass decreased by $4.47(\mathrm{P} \leq 0.05)$ and 8.07 $\% \quad(\mathrm{P} \leq 0.005)$, respectively, compared to the control. Feeding mixed feed with $20 \%$ concentrate (group III) contributed to a significant decrease in the dry matter of egg white mass by $5.3 \%(\mathrm{P} \leq 0.05)$, and with $25 \%$ (group IV) - to an increase in mineral substance by $21.1 \%(\mathrm{P} \leq$ 0.005 .

One of the main tasks of industrial poultry farming in the Russian Federation is to provide the population with affordable and safe animal products of good quality [17-19]. In this regard, it was relevant to study the safety indicators of quail eggs with the introduction of organic concentrate in the feed composition. The results concerning the content of heavy metals in the eggs are shown in table 5. 18, 19].

It was found that the cadmium and lead content in the egg mass of all groups did not exceed the normative values $(0.01 \mathrm{mg} / \mathrm{kg}$ for cadmium and $0.02 \mathrm{mg} / \mathrm{kg}$ for lead), which corresponded to the requirements of the technical regulation of the Customs Union TR CU 021/2011 "On Food Safety".

In the study of the microbiological safety of eggs in both the control and experimental groups (Table 6), E. coli bacteria (coliform bacteria) and pathogenic microorganisms, including salmonella, were not found.

The content of mesophilic aerobic and facultative anaerobic microorganisms in the egg samples of the experimental groups (I, II, III, III and IV) amounted to 1x102, 3x102, 1x102 and 2x103 CFU / g, respectively, which is significantly lower compared to the control $4.5 \times 103 \mathrm{CFU} / \mathrm{g}$. It should be noted that the content of mesophilic aerobic and facultative anaerobic microorganisms in egg samples from quail from both the control and experimental groups corresponded to the requirements of TS TC 021/2011 "On food safety" (no more than $5 \times 103 \mathrm{CFU} / \mathrm{g}$ ).

Thus, the introduction of up to $25 \%$ of organic concentrate based on DBD into the feed did not negatively affect the ecological safety of eggs.

Table 5. Content of heavy metals in eggs, $\mathrm{mg} / \mathrm{kg}$

\begin{tabular}{|c|c|c|c|c|c|}
\hline \multirow[b]{2}{*}{ 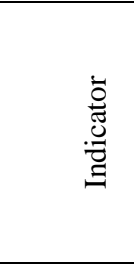 } & \multicolumn{5}{|c|}{ Group } \\
\hline & $\begin{array}{l}\overrightarrow{0} \\
\stackrel{\Xi}{0} \\
\text { U }\end{array}$ & 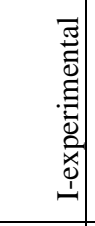 & 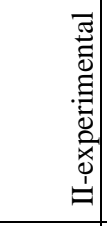 & 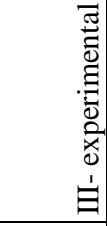 & 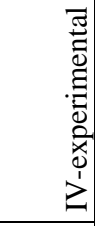 \\
\hline Cadmium & $\begin{array}{l}\text { Less } \\
\text { than } \\
0.01\end{array}$ & $\begin{array}{l}\text { Less } \\
\text { than } \\
0.01 \\
\end{array}$ & $\begin{array}{l}\text { Less } \\
\text { than } \\
0.01\end{array}$ & $\begin{array}{l}\text { Less } \\
\text { than } \\
0.01\end{array}$ & $\begin{array}{l}\text { Less } \\
\text { than } \\
0.01\end{array}$ \\
\hline Lead & $\begin{array}{l}\text { Less } \\
\text { than } \\
0.02\end{array}$ & $\begin{array}{l}\text { Less } \\
\text { than } \\
0.02\end{array}$ & $\begin{array}{l}\text { Less } \\
\text { than } \\
0.02\end{array}$ & $\begin{array}{l}\text { Less } \\
\text { than } \\
0.02\end{array}$ & $\begin{array}{l}\text { Less } \\
\text { than } \\
0.02\end{array}$ \\
\hline
\end{tabular}

Table 6. Microbiological parameters of eggs

\begin{tabular}{|l|c|c|l|}
\hline Parameter & $\begin{array}{c}\text { Coliforms } \\
\text { (CFU/g) }\end{array}$ & $\begin{array}{c}\text { QMAFA } \\
\mathrm{nM}, \\
\mathrm{CFU} / \mathrm{g}\end{array}$ & $\begin{array}{c}\text { pathogenic } \\
\text { microorganisms, } \\
\text { including } \\
\text { salmonella }(\mathrm{CFU} / \mathrm{g})\end{array}$ \\
\hline Control & not found & $4.5 \times 10^{3}$ & not found \\
\hline I-experimental & not found & $1 \times 10^{2}$ & not found \\
\hline II-experimental & not found & $3 \times 10^{2}$ & not found \\
\hline III-experimental & not found & $3 \times 10^{2}$ & not found \\
\hline IV-experimental & not found & $1 \times 10^{2}$ & not found \\
\hline Standard & $\begin{array}{c}\text { not } \\
\text { permitted } \\
\text { in } 0.01\end{array}$ & $\begin{array}{c}\text { no more } \\
\text { than } \\
5 \times 10^{3}\end{array}$ & $\begin{array}{l}\text { Not permitted in } \\
5 \times 25\end{array}$ \\
\hline
\end{tabular}




\section{Conclusion}

Based on the results of studies on the effect of organic concentrate based on DBD on the physiological state and egg productivity of quail, the following conclusions can be drawn:

1 Organic concentrate based on DBD in the amount of $10,15,20$ and $25 \%$ of the mixed feed does not adversely affect the consumption of mixed feed and the preservation of the birds, which indicates a good adaptation of quail to the new feed factor. Beginning of egg laying in quails receiving the studied concentrate occurred 3 days earlier than in the control group, which indicates some stimulating effect on egg formation.

2 Introduction of a moderate dose (10\% by weight) of organic concentrate in the feed composition contributed to an increase, and an increase in the concentrate dose $(15,20$ and $25 \%)$, on the contrary, to a decrease in quantitative indicators of egg productivity.

3 With respect to standards of biological usefulness, toxicological and sanitary-epidemiological safety, eggs of quail that received organic concentrate based on SPP met the requirements of GOST and TR TS 021/2011 "On food safety".

\section{References}

1. I. Erian, C.J. Philips, Anim., 7(3), 20 (2017)

2. Z.S. Zadeh, F. Kheiri, M. Fangani, Italian. J. A. Sci., 19, 274-281 (2020)

3. T.A. Egorov, T.N. Lenkova, Agricult. biol., 50.2, 172-182 (2015)

4. M.E. Abd El-Hack, M. Alagawany, A. Patra et al., Adv. Anim. Vet. Sci., 7(3), 218-224 (2019)

5. D. Permatahati, R. Mutia, D.A. Astuti., Trop. Anim. Sci., 42(1), 53-58 (2019)
6. A.E. Widodo, J.V. Nolan, M. Akter et al., Poult. Sci., 6(1), 41-50 (2018)

7. T.P. Lanyasunya, A. Rong et al., Int. J. Poult. Sci., 5(2), 75-80 (2006)

8. K.K. Bhargaba, J. Niel, Poult. Sci., 54, 1506-1511 (1975)

9. V.I. Solodun, Technologies and technical means of mechanized production of crop and livestock products, 80, 159-169 (2008)

10. J.B. Zhou, G.Q. Chen, Energy Policy, 35(7), 3759-3767 (2007)

11. A.E. Ghaly, K.N. MacDonald, Am. J. Agric. Biol. Sci., 7(3), 239-254 (2012)

12. J.B. Van Ryssen, Anim. Sci., 2, 1-9 (2001)

13. J.M. Oliphant, Brit. Soc. Anim., 18(2), 211-217 (1974)

14. M. Hadjipanayiotou, M.L. Louay, A.E. Kronfoleh et al., Livestock Res. for Rural Develop., 5(1) (1993)

15. N.A. Lukashik, V.A. Tashchilin, Zootechnical analysis offeed (Kolos, Moscow, 1965) $222 \mathrm{p}$.

16. O.I. Maslieva, Analysis of the quality of feed and poultry products (Kolos, Moscow, 1970) 175 p.

17. R.V. Kazarian, A.A. Fabritskaia et al., Technologies of food and processing industry of the agro-industrial complex, Healthy food, 3, 11-16 (2015)

18. R.V. Ghazaryan, L.A. Mkhitariants, A.S. Borodikhin et al., Sci. works of KubSU, 11, 42-48 (2018)

19. O.V. Cheprasova, M.V. Kondrashova, Bulletin of the Lower Volga Agricultural University, 2(18), 8 (2010) 